\title{
NAAC INDICATORS AND GOVERNMENT DEGREE COLLEGE LIBRARIES OF NORTH KARNATAKA: A STUDY
}

\author{
NIRMALA CHIGATERI ${ }^{1}$ \& SURESH JANGE ${ }^{2}$ \\ ${ }^{I}$ Research Scholar, Department of Library and Information Science, Bharatiyar University, Coimbatore, \\ Tamil Nadu, India, and Sr. Librarian, JSS College, Vidyagiri, Dharwad, Karnataka, India \\ ${ }^{2}$ University Deputy Librarian, Virtual Learning Resource Centre \& Digital Library
}

Gulbarga University, Gulbarga, Karnataka, India

ABSTRACT
Quality assessment and accreditation of institutions of higher education or units thereof, or specific academic
programmes in the accreditation process, evaluation of libraries is an essential component, Library - a central facility
which is the knowledge hub for all the departments, students and faculty occupies significance in getting better
accreditation to the college attached therein and hence, this study attempts to evaluate the college libraries of North
Karnataka covering 110 colleges with respect to the parameters like Library credibility and privileges of College
Librarian and extent of use of library services and best practices rendered by college libraries.
KEYWORDS: NAAC, Performance Measurement, Library Credibility \& Best Practices

Received: Jun 01, 2017; Accepted: Jun 20, 2017; Published: Jul 08, 2017; Paper Id.: IJLSRAUG20173

\section{INTRODUCTION}

A library is an instrument to improve the quality of life of the people giving them education, information, recreation, intellectual stimulation and enriching their life in all respects. A library well equipped and organized with services and activities imaginatively planned and executed can learn from a society into a well-informed, educated and creative contributing to its own cultural and economic progress. It is the means of communicating information between different generations and between the people of same generation. The creation of new knowledge is possible only on the firm foundation of the existing knowledge access, which is facilitated by the libraries.

The National Assessment and Accreditation Council (NAAC) is an autonomous body established by the University Grants Commission (UGC) of India to assess and accredit institutions of higher education in the country. It is an outcome of the recommendations of the National Policy in Education (1986) which laid special emphasis on upholding the quality of higher education in India. To address the issues of quality, the National Policy on Education (1986) and the Plan of Action (POA-1992) advocated the establishment of an independent national accreditation body. Consequently, the NAAC was established in 1994 with its headquarters at Bangalore. In the recent past there has been a mushroom growth of higher educational institutions with sub-standard quality of education. But after NAAC's inception, there has been a massive change in the total scenario of higher education. NAAC's assessment has brought about quality development in the colleges. There has been major improvement in the academic and non-academic activities of the college. 
There has been a dramatic change in the scope and pace of technological advances that are contributing substantially to a fundamental shift in library and information products and services, thereby, affect the roles and responsibilities of library professionals. In the context of libraries and information professionals may have to operate more differently than ever in the past. As the shift from an industrial to an information based economy takes place, there will be far more aggressive participants in the production, processing, dissemination, and distribution of information than even before. The issues before library and information professionals are how to cope with the increasing demand for information from a variety of users and use of information technology (IT) to redefine services, roles, and responsibilities. It is against this background, the quality of library should be assessed to keep going in the highly competing situation.

In recent days, researchers and librarians from all over the world have created performance indicators and methodologies for the traditional services. However, in the beginning of the 21 st century, the projects and initiatives of quality assessment involve concepts and data from communication and information technologies that have been changing libraries.

\section{LITERATURE REVIEW}

Existing literature on NAAC in general and NAAC indicators with respect to Libraries are of mainly available in the form of articles and not much in-depth studies are reported. Lokalwar and Kapade (2012) explored the various parameters of NAAC required for enhancement of college library. Antony Stella (2002) discussed case study of the National Assessment and Accreditation Council (NAAC) providing trends of external quality assurance in Indian higher education system. Johnson David and Adityakumari, H (2013) evaluated the difference in practicing of TQM application of NBA, NAAC, ISO and six sigma in Management and professional college libraries. The data were collected from 57 libraries of management colleges using a structured questionnaire. Independent samples 't' test and One way ANOVA were employed to find out difference between ISO and non-ISO certified institutions in their TQM, as well as difference between libraries accredited by different agencies. Results revealed that those management libraries with ISO certification had higher TQM practices compared to management libraries without ISO certification. Further, management libraries with EQUIS accreditation had least TQM and libraries with NBA accreditation had highest TQM practices. Jisha K. V (2015) highlights a survey report of NAAC accredited Arts and Science colleges affiliated to Kannur University. The main focus of the study is the role NAAC in quality assurance in higher education. With respect to quality, it is the buzzword in today's world of education. It has become an important ideology of education.

\section{OBJECTIVES}

The purpose of this study is to determine the extent of selected NAAC parameters met by government college libraries in North Karnataka particularly

- Library credibility and privileges of College Librarian

- Extent of use of library services and

- $\quad$ Best practices rendered by college libraries.

\section{RESEARCH METHODOLOGY}

A survey method of research using structured questionnaires been employed for the collection of data to evaluate the college libraries in the light of selected indicators of NAAC. In addition to this personal visits were made and also 
method of observation was adopted to study the problem.

Study population includes government degree colleges of North Karnataka covering 12 districts and though questionnaires were distributed manually and also using web form, out of 129 colleges, 110 colleges have responded with a feedback of $85.2 \%$.

Table 1: Study Population

\begin{tabular}{|c|c|c|c|c|}
\hline \multirow[b]{2}{*}{ Sl. No } & \multirow{2}{*}{$\begin{array}{c}\text { Districts } \\
\text { of North } \\
\text { Karnataka }\end{array}$} & \multicolumn{3}{|c|}{ GOVERNMENT COLLEGES } \\
\hline & & Total Colleges & $\begin{array}{c}\text { Total Colleges } \\
\text { Distributed }\end{array}$ & $\begin{array}{l}\text { Total Colleges } \\
\text { Responded }\end{array}$ \\
\hline 1. & Bagalkot & 12 & 12 & 10 \\
\hline 2. & Belgaum & 20 & 20 & 17 \\
\hline 3. & Bellary & 13 & 13 & 10 \\
\hline 4. & Bidar & 8 & 8 & 6 \\
\hline 5. & Bijapur & 7 & 7 & 7 \\
\hline 6. & Dharwad & 7 & 7 & 7 \\
\hline 7. & Gadag & 8 & 8 & 7 \\
\hline 8. & Gulbarga & 19 & 19 & 16 \\
\hline 9. & Haveri & 11 & 11 & 9 \\
\hline 10. & Koppal & 11 & 11 & 9 \\
\hline 11. & Raichur & 8 & 8 & 7 \\
\hline 12. & Yadgir & 5 & 5 & 5 \\
\hline & TOTAL & 129 & 129 & 110 \\
\hline
\end{tabular}

\section{RESULTS AND DISCUSSIONS}

\section{General Characteristics}

Gender and qualification of respondents and NAAC Grade of Government colleges of North Karnataka are tabulated forming general characteristics of the study. Respondents are the College Librarians serving in the Government colleges of North Karnataka.

Table 2: Gender of the Respondents

\begin{tabular}{|c|l|c|c|c|}
\hline & & \multicolumn{2}{|c|}{ GENDER } & \multirow{2}{*}{ Total } \\
\hline $\begin{array}{c}\text { Establishment of Degree } \\
\text { Colleges }\end{array}$ & & Male & Female & \\
\hline \multirow{2}{*}{ Prior to Year 2000 } & Count & 21 & 6 & 27 \\
\cline { 2 - 5 } & Percentage & $77.8 \%$ & $22.2 \%$ & $100.0 \%$ \\
\hline \multirow{2}{*}{ After year 2000 } & Count & 55 & 28 & 83 \\
\cline { 2 - 5 } & Percentage & $66.3 \%$ & $33.7 \%$ & $100.0 \%$ \\
\hline \multirow{2}{*}{ Total } & Count & $\mathbf{7 6}$ & $\mathbf{3 4}$ & $\mathbf{1 1 0}$ \\
\cline { 2 - 5 } & Percentage & $\mathbf{6 9 . 1 \%}$ & $\mathbf{3 0 . 9 \%}$ & $\mathbf{1 0 0 . 0 \%}$ \\
\hline
\end{tabular}

It is found from results of table 2 that majority of the respondents are male $(69.1 \%)$ and only $30.9 \%$ of them are female respondents. Government colleges established prior to year 2000 and later are cross tabulated with gender of respondents. Irrespective of gender of respondents, majority of the college librarians covered in the study are male. 
Table 3: Qualification of the Respondents

\begin{tabular}{|c|l|c|c|c|}
\hline \multicolumn{2}{|c|}{} & \multicolumn{2}{c|}{ Qualification } & \multirow{2}{*}{ Total } \\
\hline \multicolumn{2}{|c|}{ Establishment of Degree Colleges } & PhD & Non-PhD & 27 \\
\hline \multirow{2}{*}{\begin{tabular}{c} 
Prior to Year 2000 \\
\cline { 2 - 5 }
\end{tabular}} & Count & 4 & 23 & $100.0 \%$ \\
\cline { 2 - 5 } & Percentage & $14.8 \%$ & $85.2 \%$ & 83 \\
\hline \multirow{2}{*}{ After year 2000 } & Count & $24.1 \%$ & $75.9 \%$ & $100.0 \%$ \\
\cline { 2 - 5 } & Percentage & $\mathbf{2 4}$ & $\mathbf{8 6}$ & $\mathbf{1 1 0}$ \\
\hline \multirow{2}{*}{ Total } & Count & $\mathbf{2 1 . 8 \%}$ & $\mathbf{7 8 . 2 \%}$ & $\mathbf{1 0 0 . 0 \%}$ \\
\hline
\end{tabular}

Qualification of college librarians is depicted in Table 3. Results found that majority of the college librarians do not possess $\mathrm{PhD}$ qualification and only $21.8 \%$ of them possess doctorate in Library and Information Science, As per NAAC guidelines, higher qualification of college librarian is desirable and this is met by only $21.8 \%$ of college librarians of Government degree colleges in North Karnataka.

Table 4: NAAC GRADE of Government Degree Colleges

\begin{tabular}{|c|c|c|c|c|c|c|c|}
\hline & & \multicolumn{5}{|c|}{ NAAC GRADE } & \multirow[b]{2}{*}{ Total } \\
\hline \multicolumn{2}{|c|}{ Establishment of Degree Colleges } & A+ Grade & A Grade & B+ Grade & B Grade & $\begin{array}{l}\text { Not Available } \\
\text { or No Grade }\end{array}$ & \\
\hline \multirow{2}{*}{ Prior to Year 2000} & Count & 0 & 2 & 4 & 8 & 13 & 27 \\
\hline & Percentage & $.0 \%$ & $7.4 \%$ & $14.8 \%$ & $29.6 \%$ & $48.1 \%$ & $100.0 \%$ \\
\hline \multirow{2}{*}{ After year 2000} & Count & 1 & 3 & 6 & 41 & 32 & 83 \\
\hline & Percentage & $1.2 \%$ & $3.6 \%$ & $7.2 \%$ & $49.4 \%$ & $38.6 \%$ & $100.0 \%$ \\
\hline \multirow[b]{2}{*}{ Total } & Count & 1 & 5 & 10 & 49 & 45 & 110 \\
\hline & Percentage & $.9 \%$ & $4.5 \%$ & $9.1 \%$ & $44.5 \%$ & $40.9 \%$ & $\begin{array}{c}100.0 \\
\%\end{array}$ \\
\hline
\end{tabular}

Results from table 4 reveals that less than half of the college libraries have been accredited with B-Grade and only 9.1\% with B+ Grade, $4.5 \%$ with A Grade and only one college has acquired A+ Grade. However $40.9 \%$ of college librarians either not responded or do not possess any grade, as there is a chance of being established recently.

Library Image Building Parameters

Table 5: Vision and Mission Statement of Government Colleges

\begin{tabular}{|c|c|c|c|c|}
\hline & & \multicolumn{2}{|c|}{ Q13 } & \multirow{2}{*}{ Total } \\
\hline Vision Statement & & Yes & No & \\
\hline \multirow{2}{*}{ Prior to Year 2000} & Count & 18 & 9 & 27 \\
\hline & Percentage & $66.7 \%$ & $33.3 \%$ & $100.0 \%$ \\
\hline \multirow{2}{*}{ After year 2000} & Count & 55 & 28 & 83 \\
\hline & Percentage & $66.3 \%$ & $33.7 \%$ & $100.0 \%$ \\
\hline \multirow{2}{*}{ Total } & Count & 73 & 37 & 110 \\
\hline & Percentage & $66.4 \%$ & $33.6 \%$ & $100.0 \%$ \\
\hline \multicolumn{5}{|l|}{ Mission Statement } \\
\hline \multirow{2}{*}{ Prior to Year 2000} & Count & 18 & 9 & 27 \\
\hline & Percentage & $66.7 \%$ & $33.3 \%$ & $100.0 \%$ \\
\hline \multirow{2}{*}{ After year 2000} & Count & 55 & 28 & 83 \\
\hline & Percentage & $66.3 \%$ & $33.7 \%$ & $100.0 \%$ \\
\hline \multirow{2}{*}{ Total } & Count & 73 & 37 & 110 \\
\hline & Percentage & $66.4 \%$ & $33.6 \%$ & $100.0 \%$ \\
\hline
\end{tabular}


Table 5 shows Vision and Mission Statement of Government Colleges, which is required as per the NAAC parameter. Results found that irrespective of year of establishment of colleges, $66.4 \%$ of the colleges have Vision and Mission Statement and thus fulfilling the requirement of NAAC and only $33.6 \%$ of them negate the purpose.

Table 6: Librarian Credentials in Government Colleges

\begin{tabular}{|ll|c|c|}
\hline & Librarian Credentials & Frequency & Percentage \\
\hline a. & NSS Coordinator & 11 & $10 \%$ \\
\hline b. & NAAC Coordinator & 34 & $30.9 \%$ \\
\hline c. & In-charge Principal & 45 & $40.9 \%$ \\
\hline d. & Member of any Committee of the College & 102 & $92.7 \%$ \\
\hline e. & Earn while you Learn' scheme & 4 & $3.6 \%$ \\
\hline
\end{tabular}

Librarians are on par with Teachers and play significant role in college activities and programs in addition to the responsibility of Librarian. In addition to the regular post of Librarian, they execute the additional responsibility as NSS Coordinator, NAAC Coordinator, In-charge Principal and Member of any Committee of the College effectively. These are the additional credentials from the perspective of evaluation of college library by the NAAC. Results found that the respondent college librarians acted as NAAC Coordinator to the extent of $30.9 \%$ and $40.9 \%$ as In-charge Principal, which is a good sign of dynamism among librarians. Majority of the college librarians are involved as Member of any Committee of the College (92.7\%). But still there is a need to undertake responsibility as NSS Coordinator with other roles as well and this will really boost the image building and satisfy the NAAC parameters. Although Earn while you Learn' scheme' is desirable but almost all the college libraries do not have initiated this scheme for their students.

\section{Extent of Use of Library Services}

One of the important criteria as per guidelines of quality indicator of NAAC for college libraries is Extent of Use of Library services and this includes Average number of books issued per day, Average number of books returned per day, Average number of reference enquiries (users) made per month and Average number of users visiting the library per month.

Table 7: Extent of Use of Services

\begin{tabular}{|c|c|c|c|c|c|}
\hline \multirow{2}{*}{ Extent of Use of Services } & \multicolumn{4}{|c|}{ Total Number } & \multirow{2}{*}{$\begin{array}{c}\text { Chi-Square \& } \\
\text { Asymp. Sig }\end{array}$} \\
\hline & $25-50$ & $51-100$ & $101-200$ & $201-500$ & \\
\hline $\begin{array}{l}\text { Average number of books } \\
\text { issued per day }\end{array}$ & $\begin{array}{c}53 \\
48.18 \%\end{array}$ & $\begin{array}{c}19 \\
17.27 \%\end{array}$ & $\begin{array}{c}33 \\
30 \%\end{array}$ & $\begin{array}{c}5 \\
4.5 \%\end{array}$ & $\begin{array}{c}62.030 \\
.000\end{array}$ \\
\hline $\begin{array}{l}\text { Average number of books } \\
\text { returned per day }\end{array}$ & $\begin{array}{c}56 \\
50.9 \%\end{array}$ & $\begin{array}{c}14 \\
12.72 \%\end{array}$ & $\begin{array}{c}33 \\
30 \% \\
\end{array}$ & $\begin{array}{l}5 \\
4.5 \% \\
\end{array}$ & $\begin{array}{c}57.171 \\
.000\end{array}$ \\
\hline \multirow[t]{2}{*}{$\begin{array}{l}\text { Average number of } \\
\text { reference enquiries (users) } \\
\text { made per month }\end{array}$} & $\begin{array}{c}53 \\
48.18 \%\end{array}$ & $\begin{array}{c}17 \\
15.45 \%\end{array}$ & $\begin{array}{c}1 \\
0.9 \%\end{array}$ & $\begin{array}{c}39 \\
35.45 \%\end{array}$ & $\begin{array}{c}49.891 \\
.000\end{array}$ \\
\hline & $300-1000$ & 1001-3000 & \multicolumn{2}{|c|}{ More than 3000} & \\
\hline $\begin{array}{l}\text { Average number of users } \\
\text { visiting the library per } \\
\text { month }\end{array}$ & $\begin{array}{c}53 \\
48.18 \%\end{array}$ & $\begin{array}{c}41 \\
37.27 \%\end{array}$ & $\begin{array}{c}16 \\
14.5 \%\end{array}$ & & $\begin{array}{c}59.580 \\
.000\end{array}$ \\
\hline
\end{tabular}

Results of table 7 reveals that nearly half of the college libraries issue 25-50 average number of books per day (48.18\%) and 101-200 books are issued in 30\% of the colleges. 50.9\% of the college libraries indicated that Average number of books (25-50 numbers) returned per day are 25-50 numbers and 101-200 number. In nearly half of the colleges, Average number of reference enquiries (users) made per month is found to be between 25 to 50 queries and in $48.18 \%$ of college libraries, Average number of users visiting the library per month reported to be between 25 to 50 users only. AS 
per the NAAC, the extent of use should be optimum and higher number of visitors, issue, return of books are desirable and these results calls for further improvement in services and promotion of library sources and services.

Application of Chi-Square test to determine extent of association between colleges established and Extent of Use of Library services is found to be significant as the $\mathrm{P}$ value calculated is higher than table value at 0.05 level of significance.

\section{Best Practices}

Table 8: Best Practices of College Libraries

\begin{tabular}{|l|c|c|}
\hline \multicolumn{1}{|c|}{ Best Practices } & Frequency & Percentage \\
\hline $\begin{array}{l}\text { a. Inclusion of sufficient Information about the } \\
\text { Library in the College Prospectus }\end{array}$ & 6 & 5.5 \\
\hline $\begin{array}{l}\text { b. Compiling Student/Teacher Attendance Statistics } \\
\text { \& Locating the same on Notice Board }\end{array}$ & 2 & 1.8 \\
\hline $\begin{array}{l}\text { c. Displaying Newspaper Clippings on Notice } \\
\text { Board }\end{array}$ & 106 & 96.4 \\
\hline d. Career/Employment Information/ Services & 106 & 96.4 \\
\hline e. Signage Systems & 6 & 5.5 \\
\hline f. Suggestion Box $\quad$ Conducting Book Exhibitions on Different & 6 & 5.5 \\
\hline $\begin{array}{l}\text { g. } \quad \text { Organizing book talks } \\
\text { Occasions }\end{array}$ & 106 & 96.4 \\
\hline h. $\quad 106$ & 96.4 \\
\hline i. $\quad 106$ & 96.4 \\
\hline
\end{tabular}

Best Practices have been listed by NAAC and among them some of the best practices are enlisted in Table 8 which shows that $96.4 \%$ of the college libraries adopt best practices like Displaying Newspaper Clippings on Notice Board, Conducting Book Exhibitions on different Occasions, Organizing book talks and Instituting Annual Best User Award for Students.

\section{CONCLUSIONS}

In the changing information industry quality and excellence in librarianship occupies significant role to ensure access to timely information required by the users. Satisfaction of users is a prime concern for libraries. Results is an alarming to the college librarians to identify its strength and weaknesses for better accreditation, as it is general tendency in an college setup that a Library is blamed if the grading system from NAAC for the college is not that satisfactory. Hence, the college libraries should identify the parameters and guidelines on quality indicators in library and information services of affiliated/constituent colleges and plan from the beginning to ensure it satisfies the desired indicators to bring name and fame of the college.

\section{REFERENCES}

1. Antony Stella (2002). External quality assurance in Indian higher education: case study of the National Assessment and Accreditation Council (NAAC), Paris: International Institute for Educational Planning, pp.228

2. Bharat R. Lokalwar and Dr. Deepak G. Kapade (2012) NAAC: Quality Enhancement in college library, International Referred Online Research Journal, Issue, IV,.

3. Johnson David and Adityakumari, H (2013). Total Quality Management Practices in Accredited and ISO Certified Management College Libraries: A Comparative Study, SRELS Journal of Information Management; Vol.50 No.4,: pp 445-451 
4. Jisha, $K V$ (2015). The role of naac for quality assurance in higher education, Abhinav National Monthly Refereed Journal of Research in Arts \& Education, Volume 4, Issue 3.

5. NAAC. Guidelines on quality indicators in library and information services: affiliated/constituent colleges (http://www.naac.gov.in/docs/Guidelines-Colleges-Library.pdf) $\left(25^{\text {th }}\right.$ May 2017) 
